Instructions for authors, subscriptions and further details:

\title{
http://generos.hipatiapress.com
}

\section{Beyond bargaining: forms and mechanisms of interpersonal power}

Arlette Covarrubias ${ }^{1}$

1) El Colegio Mexiquense, A.C.

Date of publication: February 25th, 2021

Edition period: February 2021 - June 2021

To cite this article: Covarrubias, A. (2021). Beyond bargaining: forms and mechanisms of interpersonal power. Multidisciplinary Journal of Gender Studies, 10(1), 70-96. doi: 10.17583/generos.2021.5434

To link this article: http://dx.doi.org/10.17583/generos.2021.5434

PLEASE SCROLL DOWN FOR ARTICLE

The terms and conditions of use are related to the Open Journal System and to Creative Commons Attribution License (CC-BY). 


\title{
Beyond bargaining: forms and mechanisms of interpersonal power
}

\author{
Arlette Covarrubias \\ El Colegio Mexiquense, A.C.
}

\begin{abstract}
To empower women, it is necessary to better understand the power dynamics they are involved in. The objective of this paper is to analyse intrapersonal power dynamics of women with their husbands in San Felipe del Progreso, a poor and marginalised indigenous community in Mexico State, Mexico. A framework is used that distinguishes between the mechanisms that are used to enforce power and their visibility, using the forms of power proposed by (Gaventa, 2011). To achieve the objective, in-depth interviews and focus groups were applied to women of four towns in the area. Power relations related to four fundamental aspects of women's lives were assessed; women's mobility, women's contraceptive use, women's sexual relations with their husbands, and household decisions on income and expenditures. Results indicate that men and women use different forms and mechanisms of power due to gendered social norms and differences in the control and access to resources.
\end{abstract}

Keywords: women`s power, empowerment, relational power, indigenous community, Mexico 


\title{
Más allá de la negociación: Formas y mecanismos de poder intrapersonal
}

\author{
Arlette Covarrubias \\ El Colegio Mexiquense
}

\section{Resumen}

Para empoderar a las mujeres es necesario comprender mejor las dinámicas de poder en las que se encuentran involucradas. El objetivo de este artículo es analizar las dinámicas de poder interpersonal de mujeres y sus esposos en San Felipe del Progreso, una comunidad indígena y pobre en el Estado de México, México. Se utiliza un marco teórico de poder propuesto por (Gaventa, 2011) que distingue entre formas de poder, haciendo evidentes los mecanismos y visibilidad para ejercer poder. Las relaciones de poder analizados están relacionados a cuatro aspectos fundamentales de la vida de las mujeres: su movilidad, su uso de anticonceptivos, las decisiones relacionadas a las relaciones sexuales y las decisiones en el hogar sobre ingresos y gastos. Se hicieron entrevistas a profundidad y grupos focales a mujeres de cuatro pueblos de la zona. Los resultados indican que hombres y mujeres utilizan distintos mecanismos para hacer negociaciones y no todos estos son visibles. Estos a su vez dependen de las normas sociales de género y el control y acceso de recursos.

Palabras clave: poder de las mujeres, empoderamiento, poder relacional, comunidad indígena, México 
10(1)

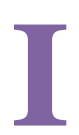

n México, as in many parts of the developing world, women face many deprivations. This is true, especially of women who live in rural areas. A large percentage of them are illiterate, have low levels of education, are undernourished and have health problems.

They also have little power, meaning they lack freedom to choose between different fundamental aspects of their lives, such as their sexuality, their movement, to work outside their home, household expenses, how to distribute their time, and on their control of household income and assets, etc. These restrictions have a direct effect on their well-being and on their access to opportunities and resources that could allow them to escape poverty (World Bank, 2012; International Labour Organization 2019).

Recognizing this, international agencies, governments and NGO`s, have promoted women's empowerment, the process by which women can make strategic life choices (Mishra, 2000; Mosendale, 2005a; Malapit, et al. 2019). Yet, much of the power dynamics in the household, the community, the work place, etc., are still not completely understood. Therefore, projects and policies to empower women might not achieve their desired effect (Doss, 2013).

To deepen the understanding of relational power dynamics in the household level, specifically between spouses, this study uses and proposes a framework that distinguishes between the mechanisms that are used to enforce power and their visibility, using the forms of power proposed by (Gaventa, 2011). It is important to distinguish between them, because diverse strategies to exercise power will have different effects on the well-being of spouses. It also helps to determine the best practices to empower women.

This framework is employed in San Felipe del Progreso, an indigenous community in México. In depth interviews and focus groups were conducted to women in this area to analyse the power relations these had with their husbands, related to four fundamental aspects of women's lives are assessed; women's mobility, women's contraceptive use, women's sexual relations with their husbands, and household decisions on income and expenditures.

Studies in diverse contexts have identified some strategies used by husbands and wives to exercise power; these also vary by their level of visibility (Silberschmidt, 1992; Amaro \& Raj, 2000; Kabeer, 2000; Gates, 2002; Mosendale, 2005b; Mannon, 2006; Contreras Urbina, 2008; Covarrubias, 2016; 


\section{Covarrubias- Beyond bargaining}

Gatwiri \& Mumbi, 2016). Some identify cases of visible strategies in which both men and women are explicitly engaged in a bargaining process. Gates (2002) for example analyses women's bargaining strategies in the household, (where) over some of their interests such as the flow of household resources, the limits of respect, to reduce their burden of housework and even their participation in employment. She finds that women`s strategies to attain these interests could be divided into offers or threats to their husbands. In the case of salaried employment for instance, the offers included to do more housework, to make a financial contribution to the household or specific large household endeavours such as building a house. The threats, on the other hand, consisted on leaving the household or to move. Similarly, Kabeer (2000) finds that in Bangladesh a common strategy used by women to negotiate with their husbands, their work in textile factories, was to invoke their children's welfare.

However, researches have also identified non-visible mechanisms to exercise power, in which individuals do not express their wants and do not explicitly enter in a bargaining process. For instance, Gatwiri and Mumbi (2016) find that in Kenya, women with vaginal fistula, use silence as a bargaining strategy with their husbands. They do this, for example, by withholding information on contraceptive use or by hiding the whereabouts of their daughters to avoid their circumcision.

Based on a literature review, Amaro and Raj (2000) analyze power relations and their effect on HIV risk among women. They distinguish between three types of dynamics of oppression (of men towards women): 1) silencing, meaning the loss of voice 2) violence and fear of violence and 3) internalized oppression where the oppressed cannot perceive clearly the social order which serves the interest of the oppressor. Therefore, these authors recognize visible mechanisms such as use of violence, but also non-visible ones such as silencing and internalized oppression. Also, the use of violence is a strategy, that affects the physical and verbal well-being of the person in the receiving end. Thus, it is a damaging strategy, compared to trying to convince the other with the use of arguments.

Thus, studies in different contexts have identified manifold mechanisms and strategies that diverge in their level of visibility and on the well-being, mainly of women. This study proposes the use of a framework of analysis to study relational power between husbands and wives, which can systematize 

10(1)

the mechanisms that couples use to enforce power and their visibility in a cohesive and comprehensive way. It is applied in San Felipe del Progreso, Mexico where the usefulness and richness of the framework is evidenced. It also revealed that strategies to exercise power are greatly dependent on social norms and some have detrimental effects on women's well-being.

To achieve the purpose of this paper, first the concepts and framework used are described. Second, the methodology and sociological characteristics of San Felipe del Progreso are displayed. Following, the mechanisms and visibility of power used by husbands and wives are classified and described. Finally, a conclusion is elaborated.

\section{Relational Power in the Household}

There is a range of conceptualizations of power. Lukes (2005) distinguishes between the broad meaning of power, potentia, referring to 'the power of things in nature, including people, to resist and act' (ibid: 73) and a more restrictive and asymmetrical definition, potestas, which implies power over another or others, and in the generic sense, to the capacity to bring about certain outcomes for individual agents and collectives.

In the generic sense, it refers to the capacities to bring about certain outcomes of individual agents and collectives. For instance, people having the power to create and build things, to teach others, to walk, to drive a car, etc. It a more circumscribed sense, it has been used to refer to the power some people have to affect or restrict the conduct and choices of other individuals (Scott, 2001). It is associated with notions of domination, subordination, control, conformism, acquiescence and docility. The latter conceptualisation is a subset of the former (Lukes, 2005).

Power relations operate at different levels in a society, at an international, national, community, relational, and individual level (Malhotra et al., 2005). Individuals seek to have power in each of these spheres and the power that individuals have on one of these levels influences the power they have in others.

In this article the focus is on interpersonal power in the household, specifically between husbands and wives. "Interpersonal power is rooted in face-to face contexts of interaction” (Scott, 2001: 28). In the specific case of 


\section{Covarrubias-Beyond bargaining}

resources in a household, Sen (1987) highlighted the problem of cooperative conflicts, where there are two simultaneous problems; one involving adding total availabilities (productive power) and the other dividing total availabilities among the members of the household (power over). This can be extended to other decision-making areas. Thus, in an interpersonal relationship it is possible to have productive power, in which both persons join their efforts to resist domination by an external person or institution. They can also have a synergy effect, a joint agency, in which they solve problems in a collective way. On the other hand, one partner may have power over the other, limiting the other spouse's opportunities and choices. This article analyses this power of one spouse over his or her partner.

To understand what determines the capacity to have power, the framework of empowerment used by feminists and based on the capabilities approach is useful. Feminists focus on the means by which women can attain power in its general and ampler meaning, but the framework is also useful to distinguish power in its more limited sense, the power over another. Empowerment is conceptualised as the process by which individual's attain the possibility to make strategic life choices, this is the process by which a person attains power (Kabeer, 1999; Malhotra et al., 2005). Kabeer, (1999) developed a framework, where the empowerment of individuals depends on three interrelated dimensions, the resources, the agency and the achievements of individuals.

The resources are not only economic ones, but also human and social, which are acquired through diverse social institutions, including the family, the market, and the community. The access to and control of resources leads to an increased capacity for power. Agency is the ability a person has to define his or her own objectives and to act in consequence. This concept incorporates not only the notion of action, but also, of significance, motivation and purpose with which individuals act, their power from within (Kabeer, 1999).

Under the same framework, authors suggest that the notion of agency is equal to that of power in its amplest sense (Malhotra, et al. 2005; Ibrahim \& Alkire, 2007). However, it is important to recognise that, having agency is as a form of power in itself and a determinant of it. For instance, when a person has self-confidence, he or she has power from within. Self-confidence also enables women to enter openly with her husband in a bargaining process, to resist violence, or to come together with other women to produce something. 

10(1)

In this paper, it will be recognised that the enhancement of a person's individual agency, influences their power that one person has over the other.

The resources and agency of a person determines their Capabilities, this is, the potential that a person has to live the life they want, of achieving different functionings that are the 'beings and doings' a person has attained. For instance, if a person has achieved to be healthy, educated, nourished, etc (Kabeer, 1999).

Authors such as Malhotra et al. (2005), Ibrahim and Alkire, (2007) and Mishra and Tripathi (2011), treat resources not as a component but as a catalyst of empowerment. Malhotra et al. (2005) argues that 'agency' should be the only component of this concept, as it captures most closely what the majority of writers refer to as 'empowerment'. In agreement with this author, in this paper resources are considered determinants rather than components of women's empowerment.

Social norms are another important factor that determines a person's ability to exercise power (Agarwal, 1997; Covarrubias, 2016). Social norms are informal moral rules that concern the principles of right and wrong behaviour as sustained by a group of individuals in a society (Rutherford, 1996). Social norms influence not only women's resources and agency but also their capacity and ability to exercise power directly. This determines the mechanisms used, and their visibility. Figure 1 presents a conceptual map of the determinants of spouses' intra-household power.

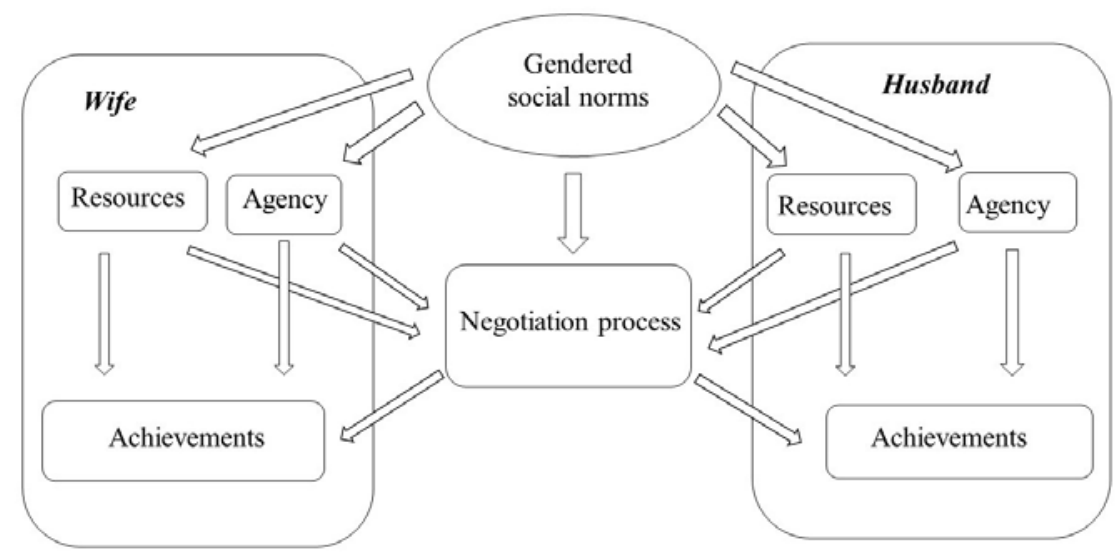




\section{Covarrubias- Beyond bargaining}

Figure 1. Conceptual map of the determinants of power at the household level.

Individuals can exercise power in different manners. Given that the mechanisms and the visibility of the strategies used to exercise power have on the agents' well-being and on the design of programs and actions that effectively challenge power over individuals or groups of people, such as women, it is key to distinguish between them.

Now we look inside the box of the negotiation process. Gaventa (2011) proposes a framework for distinguishing three types of forms of power that depend on their level of visibility. These draw on the three dimensions of power originally proposed by Lukes (2005).

- Visible power: there is explicit and observable conflict involved in controversial decisions. The conflict is about consciously-formed preferences. Observing who participates, which interests are debated, what voices are present but have little influence, who wins and who loses, can reveal who has the power. In this form of power, the actors are both conscious of their grievances and capable of articulating them, thus they have agency and the resources to enter the negotiation process.

- Hidden power: involves mechanisms in which people prevent others from expressing a conflict through the creation of barriers that prevent them participating and manifesting their preferences in the negotiating process. It also involves actions by which individuals covertly resist domination.

- Invisible power: awareness of rights and interests can remain hidden through ideologies, values, and behaviour, determined by socially constructed cultural and social patterns. Those in power might shape wants of people by shaping their belief systems through mass media or through the process of socialization. Lukes (2005) here is conceptualizing 'power as domination' to analyse its use in the political sphere. Power's third dimension then fits perfectly well with an analysis of the collective level. Yet at the relational level, because household members are not able to construct widely held social cultural patterns, it cannot be argued that one partner has explicit power over the other. For instance, it cannot be said that the husband has invisible power over his wife. Nevertheless, if the 

10(1)

wife internalises social norms in a way that affects her freedom and opportunity to achieve well-being, there is power over her.

The notion of invisible power intersects with that of social norms, as the latter influence individuals' desires and decision-making processes. Invisible power exists where there is a complete internalisation of social norms. Yet social norms can also influence manifestations of power in the visible and hidden dimensions. For instance, spouses can use social norms to justify their position when bargaining visibly.

Strategies for challenging power depend on the visibility of the form of power. Approaches that aim to transform invisible power include awarenessraising, adult education, participatory research to validate people's own knowledge, and use of the media and popular communication methods to challenge prevalent social norms. Means of addressing hidden power include strengthening people's voices and capacity to speak out and eliminating barriers to participation. Often when we talk about hidden power we talk of how people affected negatively by it may challenge it to make their voices more visible. The strategies for defying visible power involve direct negotiation and the provision of resources to the powerless (Gaventa, 2011).

It is also important to distinguish between the mechanisms that individuals use to exercise power. Agents can only use such mechanisms in the visible and hidden forms of power, because in the invisible form of power they do not directly exercise power over the other. The mechanisms that can be used are the following:

- Coercion: rests in the principal's threat of force or serious privation and the subordinate's belief that the principal has the capacity and disposition to carry out the threat (Scott, 2001).

- Manipulation: the use of lies and deceit to maintain power. The agent who conforms to the manipulation has no recognition or knowledge of the exact nature of the demand (Lukes, 2005).

- Authority: is sustained by the idea that the principal has the right to give orders and the subordinate is obliged to obey. It exists where one or several people tacitly or explicitly allow another to take decisions regarding their actions. An individual conforms because s/he is committed to the legitimacy of the source of command, and because s/he has evaluated 


\section{Covarrubias- Beyond bargaining}

the content of the action or situation to which s/he is conforming. Power is accepted because it is considered valid and correct, its legitimacy flowing from the internalisation of cultural meanings (Scott, 2001).

- Influence: is present when persuasion, operated through cognitive symbols, ideas and representations, leads people to define situations in a specific way. It takes the form of signification. In this case the individual is attracted to and influenced by the principal's interpretative frame of reference (Scott, 2001).

Some mechanisms for exercising power are more pernicious than others. For instance, coercion using physical violence is far more harmful for the receiver, than the use of influence through reasoning and convincing the other. It is therefore important to detect and analyse the mechanisms used by the household members. Interventions and programmes also need to consider the different uses of mechanisms. Figure 2 recapitulates the forms and mechanisms of power used in the negotiation process.

\begin{tabular}{|c|c|c|c|c|c|}
\hline \multicolumn{6}{|c|}{ Negotiation process } \\
\hline \multirow[b]{2}{*}{$\begin{array}{c}\text { Forms of } \\
\text { power }\end{array}$} & \multirow[b]{2}{*}{$\begin{array}{l}\text { Visible } \\
\text { Hidden }\end{array}$} & \multicolumn{4}{|c|}{ Mechanisms } \\
\hline & & Coercion & Manipulation & Authority & Influence \\
\hline & Invisible & \multicolumn{4}{|c|}{ Internalisation of norms } \\
\hline
\end{tabular}

Figure. 2 Forms of power and mechanisms used in the negotiation process.

\section{Methodology}

In this research, a Critical Realist stance is taken. It asserts that "reality has an objective existence but that our knowledge of it is conceptually mediated: facts are theory-dependent but they are not theory-determined" (Danermark et al., 2002: 15). Critical theorists begin with an initial theory which data analysis can support, elaborate, or deny, building a more accurate explanation of reality (Fletcher, 2016). In this case, we build from a theoretical framework of power, 

10(1)

described in the previous section that distinguishes the mechanisms used in the household to enforce power and their visibility.

The methodology used for this research is the one proposed by Fletcher (2017), which consists of three stages. The first, involves the identification of demi-regularities, which are rough trends or patterns in empirical data, which are obtained through qualitative data coding. Literature, concepts and the theoretical framework guide the codes, yet a flexible stance is taken in which codes are reevaluated to reformulate the theory they were based on. The second stage is that of abduction, which is defined as "inference or thought operation, implying that a particular phenomenon or event is interpreted from a set of general ideas or concepts” (Danermark et al., 2002: 205). Therefore, in this step of the analysis, empirical data are re-described using theoretical concepts, acknowledging that the chosen theory may be mistaken. The third step is retroduction, which focuses on causal mechanisms and conditions. The goal of retroduction is to identify the necessary contextual conditions for a particular causal mechanism to take effect and to result in the empirical trends observed.

A case study research method was employed to comprehensively analyse and reveal the mechanisms used by husbands and wives to exercise power in the household. Fieldwork was conducted in San Felipe del Progreso, a municipality in the northeast of the State of Mexico with a 2010 population of 121,396. It is a Mazahua indigenous community, although in 2010 only $32 \%$ of the population spoke the Mazahua language (Instituto Nacional de Estadística y Geografía, 2010). In 2010, 80.6\% of the population of San Felipe del Progreso were poor (their income was below the poverty line, defined as the minimum amount of money a household needs to purchase basic needs, including food and non-food items) and $43 \%$ were extremely poor (their income was below the food poverty line that reflects the minimum amount of money a household needs to purchase a basic-needs food bundle) (Consejo Nacional para la Evaluación de la Política de Desarrollo Social, 2010). Due to marginalisation and poverty in the area and the conservative and restrictive social norms for women, it is a research site of great interest.

The fieldwork was conducted in two stages. In the first, in-depth interviews were carried out in two areas of San Felipe del Progreso with women of all ages and varying marital status, although only information on married, 


\section{Covarrubias-Beyond bargaining}

widowed, separated and divorced women is used in the study. The sample included women older than 16 years old, of different ages. Purposive sampling was used. Specifically, interviews were applied in the localities San Lucas Ocotepec, El Carmen Ocotepec, Guadalupe Coté and San Juan Coté. The first two towns are close and well connected to the city of Atlacomulco, while the other two are further away and thus have less access to higher education, health services, and employment outside their towns. Eighteen in-depth interviews were held in both Gudalupe Coté and San Juan Coté, and 22 in both San Lucas Ocotepec and El Carmen Ocotepec.

In the second stage, focus groups were held with women from the entire San Felipe del Progreso region. In this process, questions aimed at exploring into detail themes and issues that emerged during the in-depth interviews. Group dynamics encouraged women to speak more freely about delicate topics, as they saw that other women had similar experiences as them. Purposive sampling was also used in this stage. Married women living with their husbands comprised one focus group, another consisted of married women whose husbands had migrated, and a third included only separated women. In both the interviews and the focus groups the emphasis was on the dynamics of the wives' relationships with their husbands and their power dynamics in different areas including mobility, sexual intercourse, contraception and decisions about the expenditure of household income.

Informed consent was obtained from all individual participants involved in the study. All participants were informed of the purpose of the study and no real names are provided in the articles, so participant's identities are not undisclosed.

One of the activities in the area is subsistence agriculture, mainly the cultivation of maize for self-consumption. Many single women and men migrate to take precarious jobs with low salaries and poor working conditions. Men often migrate to Mexico City or the US, where most become construction workers. Mexico City is a few hours away from San Felipe del Progreso, and those who migrate to this city for work usually return home every weekend. Those who work in the region (are not migrants) run small informal enterprises such as a bakery, or a taxi, or have precarious jobs in agriculture. Those who do not migrate are self-employed in the commerce, services, or agricultural sectors (Larralde, 2008). 


\section{GÉNEROS -Multidisciplinary Journal of Gender Studies, 10(1)}

From interviewed women's accounts showed that spouses distribute their activities according to the prevalent gendered social norms in the area. Husbands are the main economic providers, while their wives are housekeepers. The household chores include cleaning, cooking, taking care of the animals, cultivating the land, and looking after the children, the elderly and the sick. Women who engage in income-generating activities usually work in informal jobs such as washing clothes for others, preparing and selling food, cultivating other people's land, selling things, etc. The few with higher education become nurses and teachers.

Social norms strictly control women's sexuality. Women must be virgins before they marry and faithful to their husbands. Family, neighbours and the community gossip and criticise women suspected of infidelity. Women must not only be faithful, they must appear to be so as well. On the other hand, husbands infidelity is normalised; it is perceived as inappropriate, but a natural tendency of men which they cannot resist.

\section{Power Relations at the Household Level}

Interviewed women's accounts revealed that husbands exercising power over their partners in any one of the dimensions studied in this paper used diverse mechanisms whose level of visibility varied. The use of each strategy was not static but varied over time, and depended on their spouses' expected and previous responses and mechanisms. Figure 3 shows the main mechanisms, inferred by accounts of women in the sample, used by husbands and wives in San Felipe del Progreso to exercise power, and their level of visibility. Below, each of the strategies is explained and fully described, starting with husbands' strategies and followed by those of their wives. 


\section{Covarrubias- Beyond bargaining}

\begin{tabular}{|l|l|c|c|}
\cline { 2 - 4 } \multicolumn{2}{|c|}{} & \multicolumn{1}{c|}{ Men } & Women \\
\hline \multirow{2}{*}{ Visible power } & Authority & Exercise authority & \\
\cline { 2 - 4 } & Coercion & Use violence & $\begin{array}{c}\text { Threaten to leave relationship } \\
\text { Impose decision }\end{array}$ \\
\cline { 2 - 4 } & Influence & Bargaining using social norms & \\
\hline \multirow{2}{*}{ Hidden power } & Manipulation & & Hiding real actions \\
\cline { 2 - 4 } & Coercion & Anticipation violence & \\
\hline Invisible power & & \multicolumn{2}{|c|}{ Complete internalisation of social norms } \\
\hline
\end{tabular}

Figure 3. Mechanisms and forms of power relation between wives and husbands in San Felipe del Progreso.

\section{Husbands' Visible Power}

Husband's authority. Gendered social norms specify that men have authority over women. According to interviewed women's accounts it was common for people in the community to say that the men are in command in the household. This authority or command extends to many decision areas; those concerning communal household decisions such as large expenses, but also those about women's direct actions and well-being, including their movements.

In the case of wives' mobility, women asked their husbands for permission to go to places far from home. As Dalila said, 'My husband gives me authorization, if I give the next step. If he says no, well, even if you don't want to, you come back because he says no.'

Some women stated that they would not leave home if their husbands denied them permission to do so. They completely accepted their husbands' authority over them. This authority was not always absolute; sometimes when women asked their husbands' permission to leave and it was not granted they bargained for permission. Covarrubias (2016) found that women had to ask permission to go to work in two towns in another area of Mexico, Tehuacán 

10(1)

Puebla, where there are several textile assembly plants. Both towns are also in marginalized and poor rural areas, with one an indigenous community.

Women also indicated that men have authority over the household income and expenditure decisions. They are the main economic providers for the household and give their wives a proportion of their income for the daily expenses (food, school materials, etc.), which the women administer. Because the men earn the main household income they usually have the authority regarding how much money they gave their spouses. Again, a wife can bargain for more income, but the husband always has the last say. Many women said that they had trouble making ends meet, and some had husbands who spent money alcohol, clothes, hobbies, etc. for themselves even when their wives did not have enough to cover the household expenses.

Some men extended their authority to the use of contraceptives. Audelia, for example, knew that her husband was unfaithful; he had even contracted a venereal disease. Because of this, she asked him to use condoms:

If I ask him to use condoms, he tells me I'm a woman, and because I'm a woman I have to accept what he decides. 'If I want to use [condoms] I'll use them, and if I don't, I won't'.

Less commonly, some of the wives (and their husbands) believed that if the husband wanted sexual relations and the wife did not, they had no choice but to accept. As a woman in a focus group said: 'Even if you tell them no, they say yes! Especially if they're drunk.'

Therefore, men have power through their authority in decisions regarding women's fundamental functioning. This implies that women are not considered rational free adults with the autonomy to decide for themselves. This mechanism of power is supported by men's role as the economic provider for the household, and also by direct norms that give them authority over their wives and families.

Husband's influence upholding social norms. Interviewed women explained that when women bargained with their husbands the men could use women's social norms to reinforce their authority and justify their position. For instance, in the case of the women's mobility, their husbands used two main reasons to convince their wives not to leave their home. One was to 


\section{Covarrubias- Beyond bargaining}

control women's sexuality by accusing them of being unfaithful when they left their home. Celia explained:

He likes me to ask permission, because he thinks there might be people he doesn't know and that I might pay attention to them. Right now, there are only women here, but when there are men he gets jealous.

The second reason was that if the women were away from home for a long time they would not be complying with their homemaking duties; e.g. they might not have the food ready on time to serve to them. Hilaria's husband would tell her: 'If you go out you don't do the housework, you don't pay attention to the house'.

When wives did not want sexual intercourse with their husbands, the latter could employ the strategy of accusing them of not wanting it because they must be having an affair. This was the case for Esther, who indicated that when she did not want sexual intercourse with her husband he would get angry and say: 'Then maybe you're with someone else.'

Social roles are a construct that women and men internalize. Women not only believe that they must be faithful; they also believe they must appear so to others. They also believe that they must be good homemakers. When men imply that their wives are not fulfilling these roles they are targeting their sense of guilt. Husbands also assumed their wives had to comply with these roles, yet they restricted the women's freedom to achieve well-being by being free to decide when to go out and when to have sex.

Given their effect on the spouse's well-being, it is important to discover which social roles the husbands and wives make use of in their bargaining processes. The implementation of programmes aiming to erode or transform these social norms is urgent.

Husbands' coercion using violence. According to women's accounts, when a wife was denied permission to go somewhere, and she decided to challenge her husband's authority, he could respond with some sort of violence. For instance, a number of the women challenged their husbands' authority by going out without their permission. They described how the men would be verbally abusive and even physically violent when this happened. 

10(1)

This mechanism was used not only when women did not comply with their social roles but also when they asked the men to comply with theirs. Some women indicated that when they asked for more money for the weekly expenses their husbands resorted to the use of violence.

Yes, sometimes he leaves bruises on my face or where he's hit me, or he grabs me by the hair and drags me because I asked for more money and he doesn't want to [give me any more], or if I send him to work and he doesn't want to go. Then he says: 'Who are you to send me to work?' and then the beating comes.

The use of violence is one of the most damaging mechanisms for enforcing a decision on someone. It has negative consequences for mental and physical health, including depression, anxiety, post-traumatic stress, gastrointestinal problems, hypertension, sleep problems and headaches (Dutton \& Goodman, 2005). It is important to study the relationship between, power, authority and women's well-being further and more deeply. If a woman becomes empowered, by having more agency and by entering openly and defiantly in a bargaining process might have a detrimental effect, if she faces no economic and social support and has a violent husband.

\section{Husbands' Hidden Power}

Anticipation of husbands' violence. When interviewed women, based on previous experience, anticipated that their husbands were going to resort to violence they might stop expressing their wants altogether and stop bargaining. This is a case of the husbands having hidden power over their wives. For instance, in the case of sexual relations, Julieta explained how she faked not only wanting sexual relations but also enjoying it.

I say to him 'Ohh yes! That was really good'. I often fake that he's satisfied me so he won't get angry, because sometimes he says 'I feel like I'm with a stone.' So to avoid a fight, to avoid him beating me, because he has hit me [in the past], I thought I should be more intelligent and I started to fake liking it so he wouldn't beat me. 


\section{Covarrubias- Beyond bargaining}

In other decision areas the women also complied for fear of violent retribution. For example, when Juana was asked if she had to ask permission to leave the house she replied 'Yes - if I don't ask permission the beatings come.' Dutton and Goodman (2005) also identify the possibility that in interpersonal violence, the explicit statement of a threat can become unnecessary after a period of time: women know what will happen if they do not comply with their husbands' demands.

This is a covert form of power, in which men no longer need to use violence as a mechanism to exert it. However, even if women are not being victims of explicit violence, it is a pervasive mechanism, as women live in fear of serious retribution.

\section{Wives’ Visible Power}

Wife imposing decisions. A visible way in which women in the sample exercised their power was by imposing decisions. When something really mattered to them, they did it. For example, Maria wanted to construct a house. She said she had an adobe house with only one room, and it was too small. She wanted two rooms. She confronted her husband with this for a long time. He would tell that her he had no money. When her older son gave her some money she started to build the walls herself. They ended up crooked. When her husband saw that she was not going to stop, he had no choice but to finish it himself. In another case, Carmen wanted her children to take their first communion. Her husband said that it was not the time for it, but she sent her children to catechism classes anyway. He had no choice but to accept.

However, to use this mechanism successfully the women must know that their husbands will not retaliate with violence. Having a source of income besides that provided by the husband also facilitates the use of this mechanism. A son or daughter who is already economically active is a means to this end. In the case of Maria, for instance, her son's economic support was fundamental.

Wives threaten to end the relationship. A mechanism that interviewed wives used, especially when faced with their husbands' violence, was threatening to end the relationship or to leave for a while. Leaving the husband means losing the economic provider for herself and her children and facing 
social stigma, and wives only used this mechanism in the case of a serious threat to their or their children's physical integrity. This was the case, for example, for Hilaria:

I once told him that he told me off too much and got very jealous, and that I was going to leave him. 'You scold me and hit me a lot. I'm taking my three children.' He told her that he would stop, and she never left him, as she was concerned about providing for her children financially.

Nancy did leave her partner for a while. She was pregnant, and while she was very happy about this, her husband did not want her to have the baby. Her mother in law and her mother in law's sister, with whom she lived, threatened to beat her to force a miscarriage. When the aunt started saying that she would beat the baby out of her, Nancy left her husband and went back to live with her own family. Eventually her husband came to fetch her, and told her that he would accept the baby.

To be able to follow through the threat of leaving their husbands, wives must have financial and emotional support from their families. While the law states that a husband must pay child support in the case of divorce, the women did not ask for it in law. Separated and divorce women indicated that the bureaucratic process was complicated and very expensive for them.

\section{Wives’ Hidden Power}

Wives hiding their actions. Men have the authority in the household and can prevent women choosing and achieving certain functions. However, interviewed women revealed that there is a mechanism that allows women the possibility of achieving what they want without confronting their husband: they do it covertly.

Some of the women did not want to have children at the time, but their husbands did not want them to use contraceptives. To avoid conflict, they went to the health clinic for contraception without their husbands' knowledge. This was the case, for example, for Catalina: 
He was going to fill me with children, and it was difficult already with three, so I preferred to take care of myself for a while. I never told him, because if I told him... he wasn't going to agree, he was going to fill me with more children, he was going to get angry, he was going to tell me 'Why are you taking care of yourself, if you are with me?' That's why I never said anything to him. I took the decision by myself.

Women also used this tactic when they anticipated that their husbands were going to refuse them permission to leave the house for a particular purpose. They would tell them that they were going somewhere else, for example to the market or the health centre, and on the way would go where they originally intended to go, for instance to visit their mothers.

Using this mechanism, wives can get away with doing whatever they want without challenging their husbands' authority. However, they face the risk of getting caught and even greater conflict with their husbands. Authors have found that women use this mechanism in other countries. Kabeer (1999) calls this form of manipulative power informal power. She gives as an example a study by Silberschmidt (1992), who found it in Kisii, Kenya, where men had the authority and must be consulted on every type of decision, including which crops to cultivate. Yet if the wives disagreed with their husbands they rarely said anything; they simply grew what they thought best. If their husbands noticed, the women apologized and said they had planted it in because the required seed had not germinated.

While this mechanism allows women the freedom to achieve certain functionings, it is a covert method which entails manipulating information. Women do not have the freedom to explicitly bargain with and express their wishes to their husbands. They also risk being caught and facing even greater conflict. Therefore, it is not an ideal way of exercising their power.

\section{Invisible Power}

Interviewed women, and especially older women, have internalized social roles that restricted their freedom in such a way that they do not question them. Thus, even though it cannot be said that the husband exercises power over his wife, these women will not exert 'choice' because they believe that what the role or norm tells them is the correct thing to do. Some women in this study 

10(1)

had internalized the rule that women must stay at home and not go out alone. A few believed that they had to have sex with their husbands even though they did not desire it themselves. Many would never ask their husbands how much they earned and would not ask for more money even when they did not have enough for the daily expenses. Because this form of invisible power affects women's ability to choose, it influences their opportunity to achieve certain functionings.

\section{Husbands Relinquishing Authority and Power}

Some husbands of women did not exercise their authority, and thus there was no negative power dynamic between them and their and wives. Some women in the sample, indicated that their husbands controlled them less and were permissive. These husbands had relinquished their control and power over their wives. For instance, many would never deny their wives permission to leave the house. Some women even reported that their husbands had told them they did not need to ask permission to go out. This was the case for Fabiola, who said 'My husband tells me "Just let me know - I don't need you to ask permission, just let me know [when you go somewhere]."

Some men put all of their income into a common pool, and both spouses spent the money with mutual agreement.

When they pay him, he leaves the money there and tells me, it is not necessary for you to ask me for money - you can take whatever you need. Just be careful with it in case my daughter happens to get sick. Sometimes we both go shopping for what we are going to eat.

Some men respected their wives' feelings when they did not want sexual relations with them. 'When I do not want to have sexual relations with him, I let him know, and he tells me "I will wait; I will not force you to have sex with me when you don't want to." They also decided together on the type and use of contraceptives.

This mechanism treats both spouses as reasoning, free adults, and does not affect their physical integrity or self-esteem. It must be noted, however, that although a husband may choose not to exercise power he still has the capacity to do so, as there is still the acknowledgement that the husband has the 


\section{Covarrubias- Beyond bargaining}

authority and continues to be the main breadwinner. This is therefore not an ideal mechanism.

\section{Factors Influencing Mechanisms and Visibility of Power}

Diverse mechanisms of power were identified in different households and their use depended on the interrelation of social norms, resources available to women, and individual's personal agency. While it is not the objective of this article to delve into the complex relationships between these factors, the main ones will be mentioned.

It is evident from the results that mechanisms of power greatly depended on the internalisation of gendered social norms. These were internalised by individuals to diverging degrees, affecting their level of agency. Especially detrimental to women's power was the prevalent belief that men had authority over their wives. Also, when spouses bargained they could use social norms to reinforce their position and influence their partner.

The extent to which individuals would internalise social norms depends on several characteristics. In general, younger individuals and with a greater level of education believed less in them. Interestingly, individuals living in San Lucas Ocotepec, El Carmen Ocotepec which are the towns close to the city Atlacomulco, had also internalised less these norms. This could mean that interaction with people holding alternative beliefs, could lead to the modification of perceptions and principles.

Women in this area did not have many economic resources. Land, which is used for self- consumption, is inherited predominantly toby men. Many women did not have an income earning activity, and if they did, it would be an informal one. Mainly, they would be the secondary earners of the household. Therefore, women's power depended greatly on the support of family members, especially male ones. If women were welcomed back in their parents' home, they had the possibility to threaten to leave the relationship. Women with older sons, who would already perceive an income, also had a better position to bargain, especially on decisions regarding expenses.

Much more research is needed to fully understand the factors behind power relationships at the household level. Yet, a framework that distinguishes between visibility and mechanisms of power has provided useful to distinguish how different resources and social norms influence women's and 

10(1)

men's capacity to exercise power in different decision-making areas of their lives.

\section{Discussion}

Women's empowerment is fundamental to achieve their well-being. Although this is widely recognised, there is still much to understand about the power processes that women engage in with different actors and institutions. To achieve this goal, the intricate forms in which women and men exercise power need to be acknowledged. This article evidenced the usefulness of using a comprehensive framework that considers the diverse mechanisms of power that couples use and their level of visibility. Programmes which aim to successfully empower women need to consider all these strategies.

This investigation has concentrated on these dynamics in San Felipe del Progreso, Mexico, analysing the mechanisms and visibility of power in the spouses' negotiations. It finds that women in the sample and their husbands use different strategies to enforce their power. Some of these strategies are harmful to the women, especially their husbands' use of physical or verbal violence towards them to enforce their authority. The visibility of men and women's strategies also differed. Women used hidden power, resorting to withholding information, visiting their parents without their partners' knowledge; men were exerting hidden power when their wives stopped bargaining for their interests for fear of violent retribution.

While this research is a case study from San Felipe del Progreso, it is likely that these strategies are similar in other settings. There are already several studies from Mexico and other countries that have evidenced some of the varied forms and mechanisms of power in household level negotiations (Silberschmidt, 1992; Amaro \& Raj, 2000; Kabeer, 2000; Gates, 2002; Mosendale, 2005b; Mannon, 2006; Contreras Urbina, 2008; Covarrubias, 2016; Gatwiri \& Mumbi, 2016). However, much more research is needed to identify in a broad way the mechanisms and forms of power used in other settings and contexts.

Based on these findings, policies aiming at empowering women need to consider the forms and mechanisms of power used by men and women in their relationships. Strengthening women's agency and providing them with 


\section{Covarrubias- Beyond bargaining}

prospects to access assets and resources might empower some women. However, those strategies could not work if women's husbands disagree on them accessing these opportunities. They could even be detrimental to women's well-being if men resort to use violent strategies. It is fundamental for policies to focus on transforming traditional gendered social norms; those controlling women's sexuality, that establish domestic work and childrearing responsibilities as exclusive of women, that indicate that men have to be the main breadwinners, but especially norms that establish men's authority over their wives. To achieve women's empowerment, then, it is also necessary to also work with men's masculinities.

It must be noted, that this research was conducted based only on women's perspectives. A different or complementary story may be revealed if men's viewpoints are also taken into account. This remains a line of research to be investigated.

This study has addressed power strategies between spouses. It is also important to understand power relations in other areas of women's lives such as at work, in the community, etc., for a better understanding of the best means, programmes and policies for empowering women.

This article has presented the results of a qualitative study. The construction of indicators accounting for each of the strategies used by the men and women in these power processes would reveal how widespread the use of each mechanism is and determine the influence of different resources on the power strategies used by men and women.

\section{References}

Agarwal, B. (1997). Bargaining and gender relations: Within and beyond the household. Feminist Economics, 3(1), 1-51. doi: https://doi.org/10.1080/135457097338799

Amaro, H., \& Raj, A. (2000). On the margin: Power and women's HIV risk reduction strategies. Sex roles, 42(7-8), 723-749. doi: https://doi.org/10.1023/A:1007059708789

Consejo Nacional para la Evaluación de la Política de Desarrollo Social. (2010). Pobreza a Nivel Municipio 2010. CONEVAL. https://www.coneval.org.mx/Medicion/MP/Paginas/Medicion-de-lapobreza-municipal-2010.aspx 

10(1)

Contreras Urbina, J. M. (2008). La legitimidad social de la violencia contra las mujeres en la pareja. Un estudio cualitativo con varones en la ciudad de México. In Castro, R. \& Casique, I. (Eds.). Estudios sobre cultura, género y violencia contra las mujeres (pp. 41-80). Mexico: UNAM. ISBN: 978-970-32-4814-8

Covarrubias, A. (2016). La sombra voluntaria. Normas sociales $y$ participación laboral de las mujeres en la maquila. Zinacantepec, Estado de México, México: El Colegio Mexiquense A.C. ISBN: 978-607-776189-1

Danermark, B., Ekström, M., \& Karlsson, J. C. (2019). Explaining society: Critical realism in the social sciences. London: Routledge. https://doi.org/10.4324/9780203996249

Doss, C. (2013). Intrahousehold Bargaining and Resource Allocation in Developing Countries. Washington: World Bank. doi: https://doi.org/10.1093/wbro/lkt001

Dutton, M., \& Goodman, L. (2005). Coercion in intimate partner violence: Toward a new conceptualization. Sex roles, 52(11-12), 743-756. doi: https://doi.org/10.1007/s11199-005-4196-6

Fletcher, A. J. (2017). Applying critical realism in qualitative research: methodology meets method. International journal of social research methodology, 20(2), 181-194.

doi: https://doi.org/10.1080/13645579.2016.1144401

Gates, L. (2002). The strategic uses of gender in household negotiations: women workers on Mexico's northern border. Bulletin of Latin American Research, 21(4), 507--526. doi: https://doi.org/10.1111/1470-9856.00057 Gatwiri, G., \& Mumbi, K. (2016). Silence as power: Women bargaining with Patriarchy in Kenya. Social Alternatives, 35(1), 13. https://socialalternatives.com/sites/default/files/pdf/issue/free/soc_alt_vol _35_1_final_small.pdf\#page $=15$

Gaventa, J. (2011). Understanding the power cube and related concepts. Brighton, U.K.: Power Pack: Understanding Power for Social Change. Institute of Development Studies, University of Sussex. https://www.ids.ac.uk/projects/powercube-understanding-power-forsocial-change/ 


\section{Covarrubias-Beyond bargaining}

Ibrahim, S., \& Alkire, S. (2007). Agency and empowerment: A proposal for internationally comparable indicators. Oxford development studies, 35(4), 379-403. doi:_https://doi.org/10.1080/13600810701701897

International Labour Organization (2019). Empowering Women in the Rural Economy. ILO. https://www.ilo.org/wcmsp5/groups/public/--ed_dialogue/---sector/documents/publication/wcms_601071.pdf

Instituto Nacional de Estadística y Geografía. (2010). Censo de Población y

Vivienda. INEGI. https://www.inegi.org.mx/programas/ccpv/2010/

Kabeer, N. (1999). Resources, agency, achievements: Reflections on the measurement of women's empowerment. Development and Change, 30(3), 435-464. doi: https://doi.org/10.1111/1467-7660.00125

Kabeer, N. (2000). The Power to Choose: Bangladeshi Women and Labor Market Decisions in London and Dhaka. London, U.K.: Verso. ISBN: 1 859848044

Larralde, A. (2008). Mercados de trabajo en localidades rurales del centro de México: algunas características sociales y espaciales. In K. Appendini, \& G. Torres (Eds.). ¿Ruralidad sin agricultura? (pp. 79-102). México: El Colegio de México.

Lukes, S. (2005). Power. A Radical View (Second edition ed.). Hampshire and New York: Palgrave Macmillan. ISBN: 0-333-42092-6

Malapit, H., Quisumbing, A., Meinzen-Dick, R., Seymour, G., Martinez, E. M., Heckert, J., \& Team, S. (2019). Development of the project-level Women's Empowerment in Agriculture Index (pro-WEAI). World development, 122 , 675-692.

doi:

https://doi.org/10.1016/j.worlddev.2019.06.018

Malhotra, A., Schuler, S., \& Boender, C. (2005). Women’s empowerment as a variable in international development. In D. Narayan, (Ed.). Measuring empowerment: Cross-disciplinary perspectives (pp. 71-88). Washington D.C.: Gender and Development Group, World Bank.

Mannon, S. E. (2006). Love in the time of neo-liberalism: Gender, work, and power in a Costa Rican marriage. Gender \& Society, 20(4), 511-530. doi: https://doi.org/10.1177\%2F0891243206288042

Mishra, S. (2000). Women's empowerment through NGO interventions: A framework for assessment. Social Change,30(3-4), 44-63. doi: https://doi.org/10.1177\%2F004908570003000405 

10(1)

Mishra, N. K., \& Tripathi, T. (2011). Conceptualising women's agency, autonomy and empowerment. Economic and Political Weekly, 46 (11), 5865. doi: https://www.jstor.org/stable/41151972

Mosendale, S. (2005a). Assessing women's empowerment: towards a conceptual framework. Journal of international development, 17(2), 243257. doi: https://doi.org/10.1002/jid.1212

Mosendale, S. (2005b, October). Strategic Impact Inquiry On Women's Empowerment. Care. http://www.aic.ca/gender/pdf/CARE_Impact.pdf

Rutherford, M. (1996). Institutions in Economics: The Old and New Institutionalism. Cambridge, U.K.: Cambridge University Press. ISBN: 9780521574471

Scott, J. (2001). Power: Critical Concepts in Sociology. Malden, M.A, U.S. and Cambridge U.K.: Polity Press \& Blackwell Publishing Ltd. ISBN 9780415079389

Sen, A. (1987, July), Gender and Cooperative Conflicts, (WIDER Working Papers WPI8), WIDER.

https://www.wider.unu.edu/sites/default/files/WP18.pdf

Silberschmidt, M. (1992). Have men become the weaker sex? Changing life situations in Kisii District, Kenya. The Journal of Modern African Studies, 30(2), 237--253. doi: https://doi.org/10.1017/S0022278X00010703

World Bank (2012). World Development Report 2012 : Gender Equality and Development.

World Bank. https://openknowledge.worldbank.org/handle/10986/4391

Arlette Covarrubias: El Colegio Mexiquense, A.C E-mail address: acovarrubias@cmq.edu.mx 